\title{
ORRION: A specific information sharing tool to (re)build a "flood risk culture" in the Rhine Graben (France - Germany)
}

\author{
Brice Martin ${ }^{1}$, Florie Giacona ${ }^{1}$, Benjamin Furst ${ }^{1}$, Charlotte Edelblutte ${ }^{1}$, Nicolas Holleville ${ }^{1}$, Marie-Claire Vitoux ${ }^{1}$, Rüdiger \\ Glaser $^{2}$, Iso Himmelsbach ${ }^{2}$, Johannes Schonbein ${ }^{2}$, Carine Heitz $^{3}$, Patrick Wassmer ${ }^{4}$, Emma Haziza $^{5}$, Luc Christiany ${ }^{6}$ \\ ${ }^{1}$ CRESAT - UHA, Campus Fonderie, 16 rue de la fonderie 68093 Mulhouse cedex, France \\ ${ }^{2}$ IPG, Alert Ludwig Universität, Werthmannstraße 4, 79098 Freiburg, Germany \\ ${ }^{3}$ GESTE - IRSTEA, ENGEES, 2 quai Koch 67000 Strasbourg, France \\ ${ }^{4}$ LGP, 1 pl. Aristide Briand, 92195 Meudon cedex, France \\ ${ }^{5}$ MAYANE, 173 Chemin de Fescau, 34980 Montferrier-sur-Lez \\ ${ }^{6}$ CYSTEM SAS, Strasbourg http://cysteme.fr
}

\begin{abstract}
When is led a prevention initiative concerning flood risk, the recall of old events allows just as much to act as pedagogy to legitimize the initiative. So as it is written in the information leaflet on the "Plan de Prévention des Risques d'Inondation" (PPRI): «Alsace did not know any more exceptional floods since 1910. In almost a century, the flood risk thus naturally faded of our memory". A paradoxical assertion because the floods of 1910 are not taken into account for risk mapping. Only the recent floods $(1983,1990)$ are used as benchmarks. We were able to show [1] that, although legitimate as reference events, the floods of 1910 and many others had become manifestly underestimated for multiple reasons connected to the history of Alsace, or due to disorganization of the archives. Worse, these risks unawareness is shared by all the actors, causing problems of acceptance of the risks and their management, and an additional vulnerability in terms of population behavior before, during and after the crises. This is the reason why an online participative database (ORRION) has been created. The objective of this database is to inform and to share the information about flood history, in the particular context of a cross-border territory (France, Germany, Switzerland). This tool has been immediately involved into risks prevention actions (PAPI, PPRI).
\end{abstract}

\section{Introduction}

Regarding flood risks, the Rhine Graben (Fig.1) is in a rather particular situation. The dikes of the Rhine would indeed allow the passage of an extrem event $\left(\mathrm{Q}_{1000}\right)$ without risk of flood, numerous streams have been rectified, big cities are protected by discharge channels [2], and rural villages by numerous stormwater basin. Nevertheless, the two alsatian departments appear among the 20 departments most at risks of flood in France. Between climatic fates and artificialization, small and average floods disappeared and the destructive events have become increasingly rare, the last one, in regional scale, taking place in year 1990. Mulhouse, for example was not flooded anymore by overflowing for more than a century [3]. Through lack of experience or of "familiarity" [4], flood risk is thus gradually forgotten or under - estimated, the actors being less prepared to face floods. This is why it is important, particularly here, to restore a "risk culture" [5], a subject whose importance has been particularly reminded of by minister Ségolène Royal during the "Assises Nationales des Risques" 2016.

The absence of "risk culture " is indeed, systematically evoked after disasters, even if the term in itself does not benefit from a clear scientific definition [5]. Numerous authors underline nevertheless the existing

\footnotetext{
a Corresponding author: brice.martin@uha.fr
}

links between culture and memory [6, 7, 8, 9], favoring the territorial anchoring of the risk and its acceptance [10], in particular because of the increase of the mobilities [11]. The preserving of this memory allows the information, the education, in particular concerning the behavior and the best practice $[12,13]$. It is thus to that end that the website ORRION (Observatoire Régional des Risques d'Inondation) has been set up, for the Rhine Graben, integrating sharing and exchange, which values the local knowledges and the regional characteristics (bilingualism, cross-border region).

\section{2 "Risk culture": situation in the Rhine Graben}

The national surveys on risk perception produced by the French Institute of Environment [14] show that Alsatian citizens declare that earthquakes are the risks in which they felt the most exposed. This result is particularly incoherent in relation to the level of exposure to earthquakes in Alsace: the risk is considered as "very low" and within the last 35 years, there was only one declaration of natural disaster ("état de catastrophe naturelle ») in Colmar (South part of Alsace) for one single damaged house in 2002. 


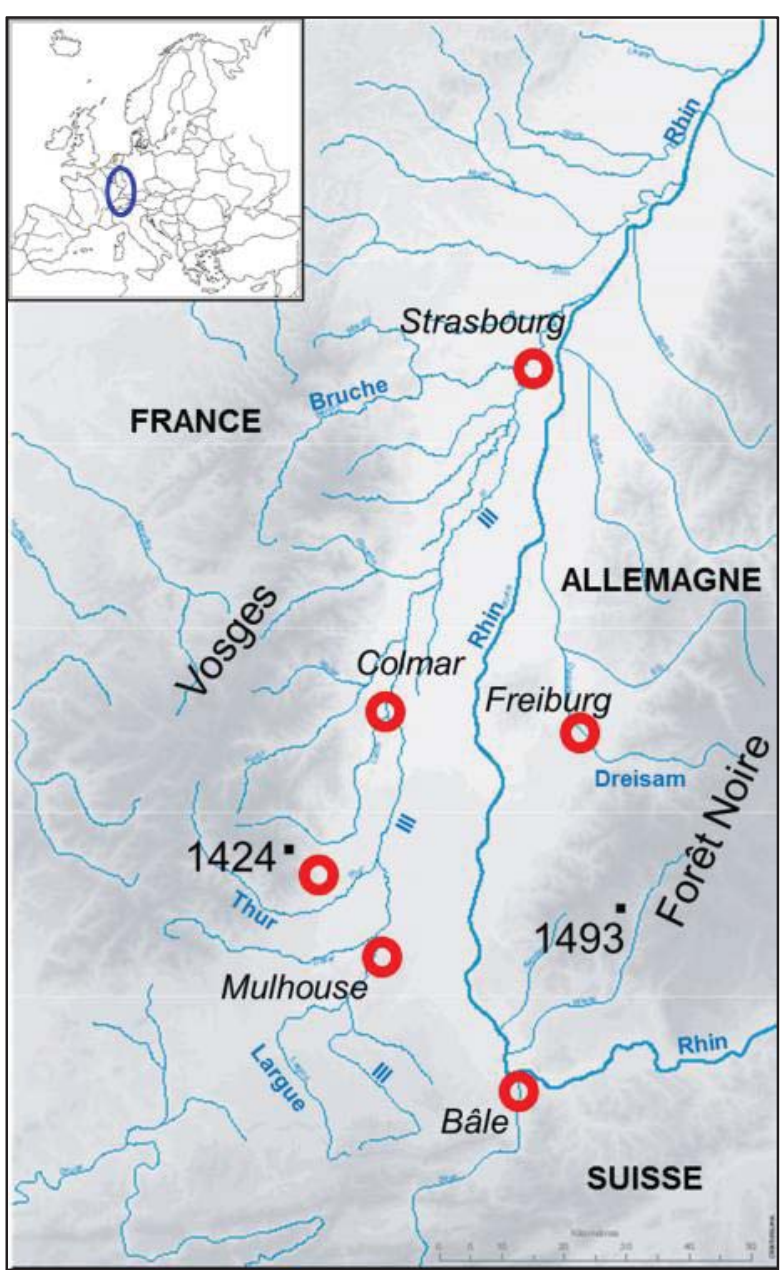

Fig.1: Topography and hydrology in the Rhine Graben

Four main factors can explain this gap between the objective level of exposure and the perception of the citizens: (1) the importance of a short-term memory linked to the earthquakes' sequences of 2002 and 2003; (2) effective communication campaigns mainly done by the anti-nuclear activists; $^{\mathrm{a}}$; (3) earthquakes seem to be more impressive and (4) their infrequency in Alsace compared to floods $[15,16]$ or muddy floods [17], for instance. At the opposite, the floods that occurred in 1990 led to many deaths, strongly damaged houses or infrastructures $[18,19]$. But, 15 years elapsed between these two natural disasters and the risk perception level is decreasing with the time [20]: the perception of the 1990's floods sequences (which affected more than 300 municipalities in Alsace) is considered by the population as less important than the latest earthquake event. Memory lapses, ignorance of past events even if they are very frequent, risk denial, or misperception of the probabilities of exposure, $\ldots$ are the main factors that can explain why people forget natural disasters or underestimate their exposure to them. The Rhine Graben is an interesting area for such a study because a real

\footnotetext{
${ }^{a}$ The nuclear power plant of Fessenheim is one of the major installations that could be seriously threatened by an earthquake in this region. Communication and information campaigns are done by the anti-nuclear lobbies to highlight the high level of exposure of the population in case of an earthquake event.
}

difference of risk memory (mainly by communicating on past events) exists between the French and German sides [21].

\subsection{Historic analysis of a "risk culture" emergence in France and Germany}

From a historical perspective [22], it seems very difficult to identify a real emergence of a "risk culture" on both sides of the Rhine Graben, and more precisely in Alsace. The first explanation lies in the particular history of this territory with three French-German conflicts between 1870 and 1945 [23]. During these 75 years, Alsace changed its nationality, its administration system and its language five times. All these radical changes explain why actions to maintain risk memories or to develop a "risk culture" were not the major priorities for the local authorities. In fact, a significant part of information on past events included in local archives have been destroyed or lost and those which are still available are sometimes very hard to understand or interpret for laypersons: particular and imprecise classifications, documents and press in German and in Gothic script, etc. It is particularly problematic for the period between 1870 and 1918 during which people had to face the strongest floods of the last 150 years (i.e. $1876,1882,1910,1919 ;[24,25])$. Due to all the difficulties to compile and gather data on these floods, these events remain widely underestimated by the local authorities and the citizens [26]. It is also worth noticing that the memory of the two world wars is more important for the local historical societies' publications than the questions related to the natural hazards and their associated risks.

Furthermore, strengthened by effective protection infrastructures and measures on the Rhine River and its tributaries, the main Alsatian and Bade-Württemberg cities (Strasbourg, Mulhouse and Freiburg in Breisgau) have not been exposed to significant floods since the end of the XIX ${ }^{\text {th }}$ century [27]. Even if the floods that occurred in February 1990 were destructive, they mainly damaged the South part of Alsace while the right side of the Rhine River (Bade-Württemberg) was spared. To find events that damaged the both sides of the Rhine graben, it is necessary to have a look at the floods of January, 1955, December, 1919 and January, 1910. These two last events were the most destructive flood sequences on the Rhine River and its tributaries [28]. One more time, for these events, the archives and information sources are numerous but hard to decipher for the reasons cited above.

The "risk culture" appears to be better on the German side: the Bade-Württemberg was more stable during the two World Wars considering administrative and linguistic aspects. The damages due to the three main FrenchGerman conflicts were also less important in this region than in Alsace, even if the bombings during the WWII were extremely strong. This situation explains why we can find on the Germany side of the Rhine Graben ten times more flood marks than on the French side [29] (Fig.2). These floods marks are also well preserved 
because they were placed on modern engineering works (second part of the XIX ${ }^{\text {th }}$ century) that are still in activity. Moreover, the Bade-Württemberg land organizes regularly special exhibitions on floods ("Hochwassertag", Fig.3). The objectives of these exhibitions are: (1) to inform the population of their objective exposure to the flood risk, (2) to inform the population of the issues linked to the risk management and the missions of all the local stakeholders and (3) to encourage the population to subscribe individual insurance policies. But even in Germany, "people usually forget the flooding quickly, and, a few years later, they are less prepared to accept measures to prevent it ${ }^{\mathrm{b}}$."

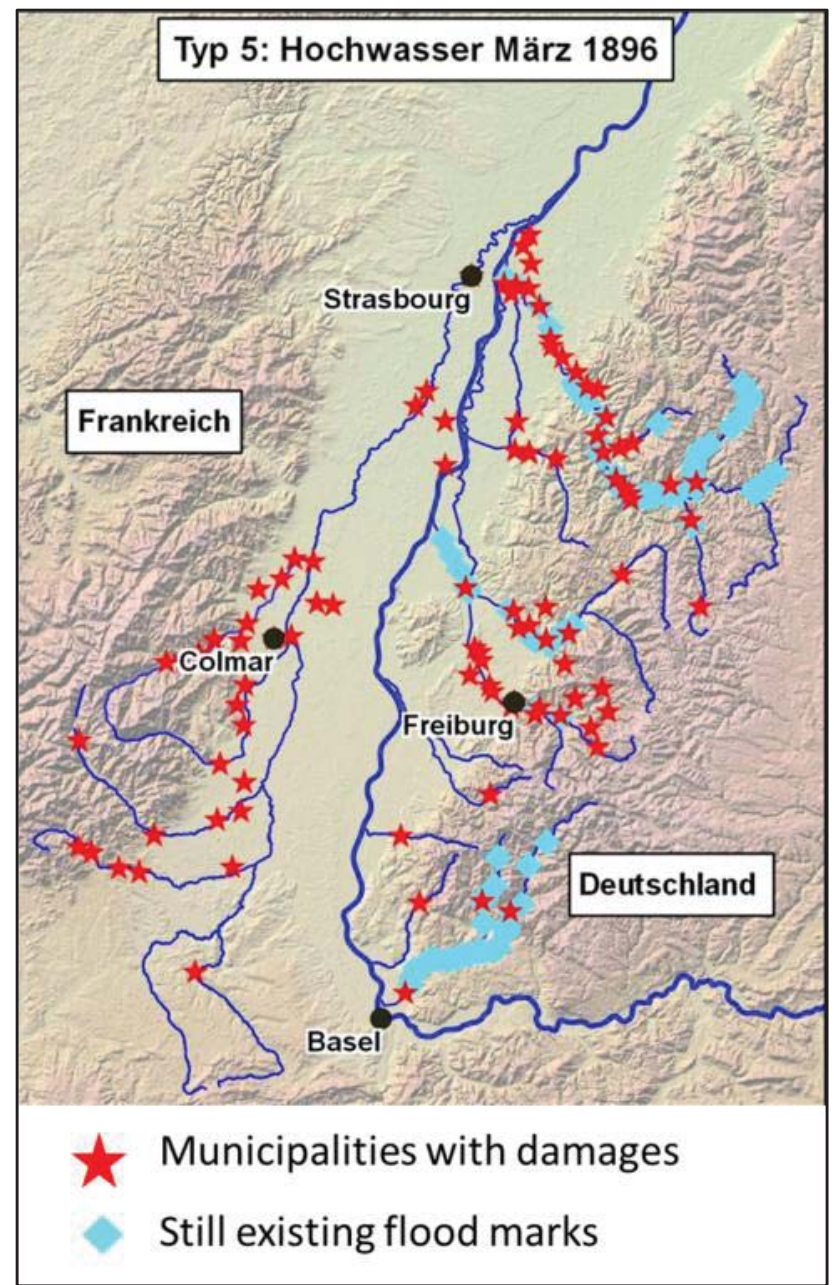

Fig. 2: location of flood marks in the Rhine Graben for the flood of March 1896. Damages can be found in all the area but all flood marks in Alsace have been destroyed and can't be found anymore nowadays.

\footnotetext{
b Deutsche Welle, 12/06/201: «German flood prevention still can't prevent floods ».
}

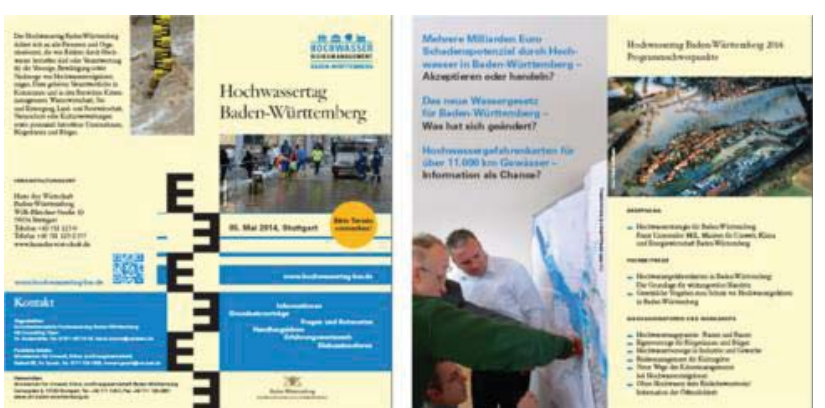

Fig. 3: « Days of Floods », public event about flood risks information in Bade - Wurtemberg (Germany)

\subsection{Late awareness of public authorities}

This cross-border territory is well known for its very high population density and its accelerated urbanization mainly in the rivers' floodplains [30]. For generations, this urbanization is effective but now, the drastic increasing of individuals' mobility, the loss of intergenerational transmissions and the lack of actors' empowerment led to gradually modify the link between past and present life territories dynamics. One of the principal consequences connected to this assessment in Alsace is a real lateness in the administrative risk management procedures [31], such as the "floods risk prevention strategies" (PPRI "Plan de prévention des risques d'inondation") or the "municipal saving procedures" (PCS "Plan Communal de Sauvegarde"). These slowness lead to a complete indifference (or sometimes to a violent rejection) of the administrative procedures from the population and the local stakeholders $[32,33]$. Thanks to the European "Flood" Directive and its associated procedures, the local stakeholders are strongly invited to accelerate the instruction of all these risk management tools. In this framework, a census of all the historic floods events has been realized. It revealed the exposure to floods of thousand people and $i$ ) induced a sudden acceleration of the risk management procedures in the Bas-Rhin department; ii) raised the stakeholders' awareness to invest in their territories' protection. Due to the redefinition of all the missions incumbent upon the French State, new floods management tools and funding are now available. But, to qualify for these funding, the municipalities must undertake actions linked to the commemoration of past events (i.e.: by placing flood marks) and to the promotion of a consistent "risk culture".

On the German side, the main issue is to reintroduce the awareness that important floods could occur in the region. In fact, the position of the oldest highest flood marks seems to show that the correction of the main rivers (XIX ${ }^{\text {th }}$ century) allows to decrease the number and the severity of modern floods. This engineering work and the feeling that floods can be controlled induce a misperception of this risk by the population and the stakeholders. 


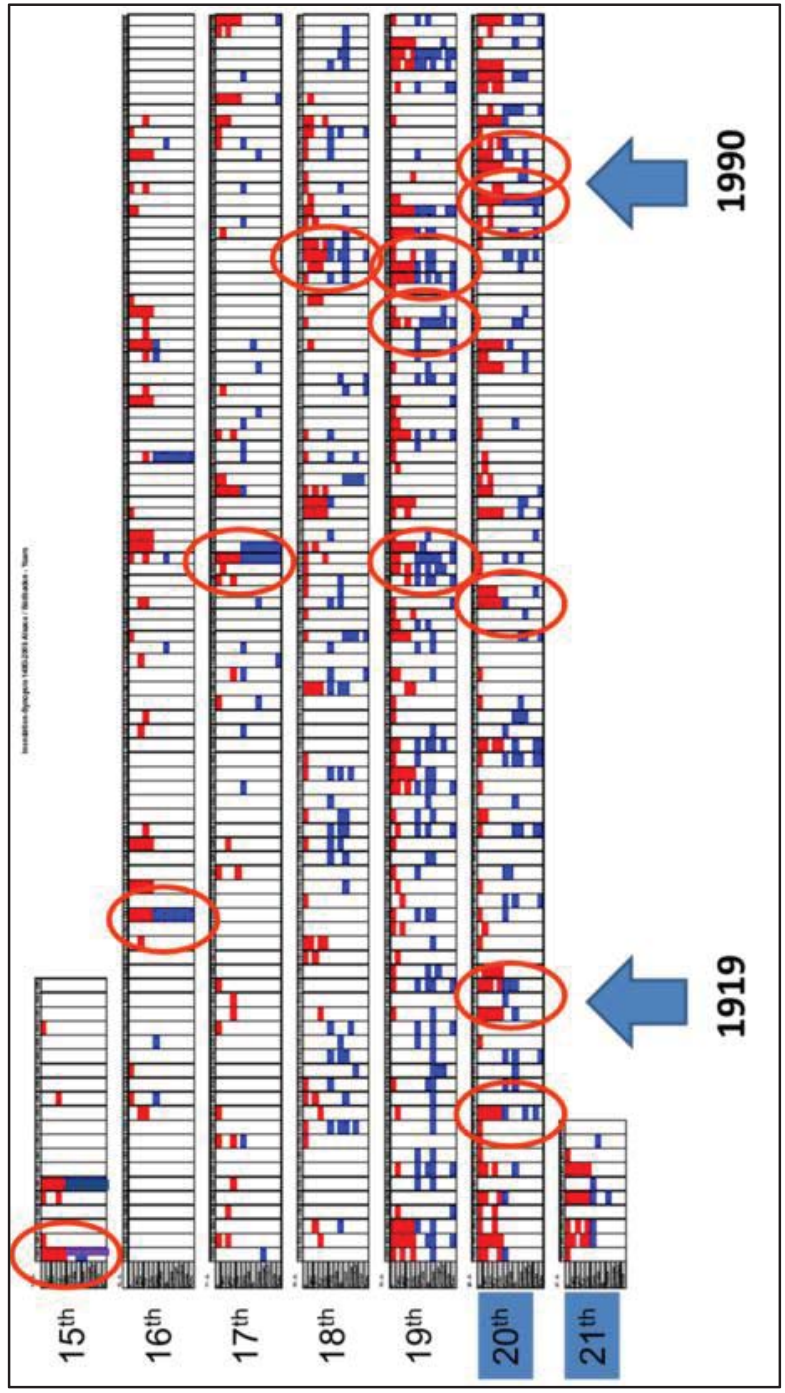

Fig.4: chronology of the floods between 1480 and 2010 in the Rhine Graben. French rivers are in red, German rivers in blue. The red circles show the highest floods, just like 1919 or 1990.

The French-German programs ANR-DFG TRANSRISK $^{\mathrm{c}}(2008-2011)$ and TRANSRISK ${ }^{2 \mathrm{~d}}$ (20142017) allow the researchers to constitute a database on the historic floods in the Rhine Graben (1480-2015; Fig.4) $[34,35]$. The database supplies all the information needed to implement a "risk culture". Citizens and local authorities can also contribute to supply this database by introducing their own information, experience, feedback on past / modern flood events. The ORRION database ("Regional Observatory of Flood Risks", cf. 3rd part) was designed and offers the opportunity to the citizens and stakeholders to contribute to the emergence of a common

\footnotetext{
${ }^{\mathrm{c}}$ TRANSRISK (analyse interdisciplinaire et transfrontalière de l'histoire des risques d 'inondation dans l'espace du Rhin supérieur): http://www.agence-nationale-recherche.fr/projetanr $/$ ?solr=run\&tx_lwmsuivibilan pi $2 \% 5 \mathrm{BCODE} \% 5 \mathrm{D}=\mathrm{ANR}-$ 07-FRAL-0025

${ }^{\mathrm{d}}$ TRANSRISK $^{2}$ (Transnational flood risk management in the Rhine Bassin : A historic-progressiv approach): http://www.agence-nationale-recherche.fr/?Project=ANR-13FRAL-0012
}

transmission of past events, on both side of the Rhine River Graben.

\section{The online and participative database: ORRION}

\subsection{From the TRANSRISK database to ORRION}

TRANSRISK database was the first step of the implementation of an online and participative database. The main information that is now available in ORRION arises from the TRANSRISK database and the first challenge was to input all the information in a same database. The data on all historic floods that occurred in the Rhine Graben (characteristics, intensity, management, etc.) were gathered by a precise analysis of archives documents and spread over a period between 1480 and 2015 [36]. These data encompass all the rivers of Alsace (French side) and Bade-Württemberg (German side) as well as the Rhine River. Information concerning the Moselle and Sarre were recently added to this database. The reason is fourfold:

- to study more precisely the behavior of rivers located on the both sides of the Vosges mountains (western slopes are more exposed to heavy rainfall (Lorraine side) while eastern slopes are leeward (Alsace side),

- $\quad$ to evidence rivers behavior similarities or disparities between western slopes of Vosges and Black-Forest mountains,

- to introduce an additional cross-border risk management analysis: the Moselle and the Sarre Rivers are flowing in France, then in Germany,

- to adapt our analysis to the administrative subdivisions: the Rhine-Meuse ("Agence de l'Eau Rhin-Meuse") or the "Grand Est" region are both in charge of the floods risk management and ORRION database could then cover the same territory.

The database contains more than 3.000 events with a variety of gravity and extension (some major events concern simultaneously the Rhine and its French and German tributaries - i.e. 1480, 1651, 1778, 1876, 1882, 1910, Fig.4). We are aware that the TRANSRISK database is a researchers' tool. That is to say that it is designed by researchers and for research, without any operational objectives. The second challenge of the transposition of the TRANSRISK database to ORRION consists in the information's accessibility for all users (citizens and stakeholders) and in its operational effectiveness.

\subsection{Observatories and online databases on diachronic information: state of the art}

This online and participative ORRION database is operational since the beginning of 2015 and all the reflections on its design have been conducted in 2014. To create this database and its structure, we undertook a state of the art of all the existing databases on flood risks, such 
as: the National Observatory of Natural Risks $\left(\mathrm{ONRN}^{\mathrm{e}}\right)$; the database on the Historic Flood Events $\left(\mathrm{BDHI}^{\mathrm{f}}\right)$ done in the continuation of the European "Flood" Directive; the database produced by the $\mathrm{RTM}^{\mathrm{g}}$ services ("Restauration des Terrains en Montagne") focused on the Alpine and Pyrenean regions. These databases are all conducted by state services at a national level. It sometimes dilutes the regional information and does not necessarily take into account the local particularities (especially for the Rhine Graben region when the available data are in German language).

Assuming a regional point of view, the ORRM ${ }^{\mathrm{h}}$ observatory in Provence - Alpes - Côte d'Azur is interesting. But the web interface to reach information is often rather complex and little attractive. Furthermore, the "collaborative" aspect is only focused on the participation of the government services, restricting the citizens' appropriation of this tool. The Floods Observatory of Franche-Comté contains a huge amount of data, localized information, endowed with an accessible and attractive interface, but no direct contributions are allowed.

The appropriation by the population and the localization of all the data are the two main points for ORRION. The lack of documentation on extreme flood events and problems due to the historical context of Alsace can be overcome thanks to the population's contributions. One of the major difficulties is then to create a design allowing an easy and fast data input for the contributors. Another main issue is to limit the cost of maintenance of the online interface to guarantee the continuity of a structure without long-lasting sources of funding.

\subsection{Presentation of the ORRION website's design}

The ORRION website is totally funded by the FrenchGerman ANR-DFG TRANSRISK ${ }^{2}$ program. Its design is built as a user-friendly, easy and shared tool (Fig.5). Its structure doesn't lean on a "classic" online database (to minimize all the management difficulties) but is built on a blog structure (WordPress type). All information concerning a specific flood corresponds to one entrance in the blog, with a specific indexation, allowing a research by keywords. The huge amount and the complexity of the information contained in the TRANSRISK database will probably require several years before the entire data will be available on the ORRION website.

The ORRION website interface will progress in the next months in its presentation and in its contents. Firstly, the site is intended to inform and to share floods' information in the particular context of a cross-border

\footnotetext{
${ }^{\mathrm{e}}$ ONRN (Observatoire National des Risques Naturels): http://www.onrn.fr/

${ }^{\mathrm{f}} \mathrm{BDHI}$ (Base de Données sur les Inondations Historiques): http://bdhi.fr/appli/web/welcome

${ }^{\mathrm{g}}$ http://rtm-onf.ifn.fr/

${ }^{\mathrm{h}}$ ORRM (Observatoire Régional des Risques Majeurs): http://observatoire-regional-risques-paca.fr/
}

territory. This is why the site presents a bilingual character (French and German) and should be, in the future, trilingual by adding a dialectal version in Alsatian (to increase the participation of older people who are the "holders" of the memory for past events). Secondly, ORRION website will also gather data on other natural disasters such muddy floods and snow avalanches (with the development of the site ORRIA: regional observatory of the risks of avalanches in Alsace). ORRION will also be developed on other territories: it will be a trinational tool (including information on the historic floods in the cantons of Basel in Switzerland). Finally, from 2017, ORRION will supply local information on the status of the administrative procedures (PPRI, PCS, etc.) as well as the factual, technical and legal watch (on the reference model of the «Institut des Risques Majeurs $\left.{ }^{i} »\right)$.

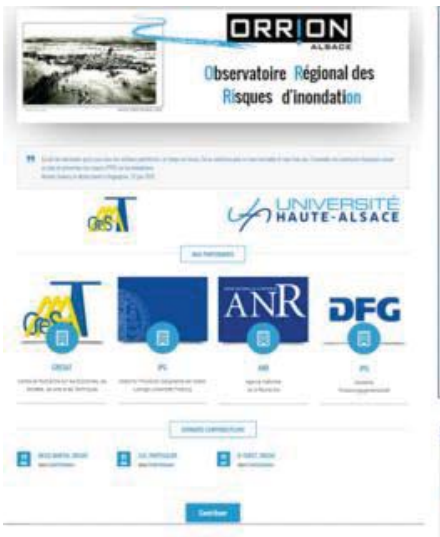

Fig.5: ORRION's homepage and the interface of the online database, and the Facebook page of ORRION.

Still in a perspective of sharing, communication and information, ORRION benefits from a relay on a Facebook page (Fig.5) intended to increase the visibility and the attractiveness of the website, via the regular publication of photos or former postcards.

\subsection{Online and participative website: limits and main issues}

The launch of ORRION website went along with several communications actions, such as articles in the regional newspapers, specific newsletters sent to local stakeholders, distribution of flyers in specific sectors in Alsace (such as sectors involved in administrative procedures to manage floods). All these communication actions had at the same time interesting and frustrating feedbacks. They allowed us to gather new information, especially by the local "History Societies" (which organized events in 2016 related to the launch of ORRION website) but direct inputs on ORRION were very scarce. This can be explained by the age of the contributors (50 years old and more in average). Oldest people are not always familiar with online databases and prefer providing their personal data to local stakeholders or ORRION designers leaving them the responsibility to

\footnotetext{
${ }^{\mathrm{i}} \mathrm{http} / / / \mathrm{www}$. irma-grenoble.com/
} 
input the information on the website. And this high average age of people showing an interest in the floods risk management is also revealing the regional reality: at that scale, no major event was census in the last 25 years. Involving younger people, who did not have to cope with any major event, constitutes a real challenge.

\section{ORRION: how to help the local stakeholders to implement prevention actions?}

Local stakeholders' interest for a complete census of historic floods had already been proved during the program TRANSRISK (2008-2011). It ended by their involvement, in the framework of the European "Flood" Directive's application, in a preliminary investigation of the risk of floods (EPRI - "Evaluation Préliminaire $d u$ Risque d'Inondation" [37]). It continues by their participation in the steering committee of a new land use planning action (TRI - "Territoire à Risque d'inondation Important"[38]) in Alsace [39]. For instance, in Mulhouse, as part of one of these steering committees, the historical reconstruction of the 1860's floods spatial extension was compared to the current modeling. The two zonings were superimposed to highlight the spatial convergences and differences. A pedagogic and educational dimension was then given to the usefulness of historic data in current flood risks calculation and indirectly flood risk management policies.

These collaborations between local stakeholders and ORRION's researchers led the strengthening of the development of a "risk culture" in a context of floods' unfamiliarity and lack of citizens' interest for this question. Information on historical floods extracted from the ORRION database were recently used within a partnership between the ORRION's researchers, MAYANE $^{j}$ and a local risk management stakeholder (DDT - "Direction Départementale du Territoire”, BasRhin). This collaboration illustrate how important are information and communication campaigns before the fulfillment of the PPRI (Bruche River, Ill River, Moder River, Giessen-Liepvrette Rivers, Fig.6). It allows all the local actors (citizens, stakeholders, researchers) talking about the floods risk management issues (from the past to the current situation). These debates and discussions were analyzed after all the local meetings (10) and the results lead to three main conclusions:

Although the Bas-Rhin department is one of the 20 departments with a high level of flood risk exposure, it is also characterized by a significant lateness in the implementation of the PPRI procedures. It was important to set up a procedure guaranteeing a fast catching up of the delay by avoiding the obstruction of the local actors (justifying the importance of information and communication campaigns done before the PPRI procedures),

\footnotetext{
${ }^{\mathrm{j}}$ MAYANE is a consulting structure specialized on risk management (based in Montpellier, France): http://mayane.eu/
}

- The previous PPRI procedures in Alsace (particularly in Haut-Rhin department) aroused violent and hostile reactions from both the population and local stakeholders [36]. These oppositions and controversies were then totally harmful to the procedures' progress. The insufficiency of communication and information campaigns explains the main failures of the risk prevention actions: the PPRI procedures were perceived by the actors as a "bottom-up policy", totally disconnected from the local realities,

- There is a real deficit of "risk culture" in Alsace. There are several (and complex) reasons to explain this acculturation. One of those is the absence of catastrophic event in the Rhine Graben for at least 25 years, favoring the misunderstanding, the memory lapse and, sometimes, the denial of flood risk. Using a geohistoric approach (i.e.: presentation of the past floods events by requesting ORRION dataset, presentation of the chronology of the PPRI procedures and implementation on a regional scale, etc.) allows to provide enough information to legitimize the procedure, to favor its acceptance and its appropriation [40] while fighting straightaway any idea of disparity between territories.

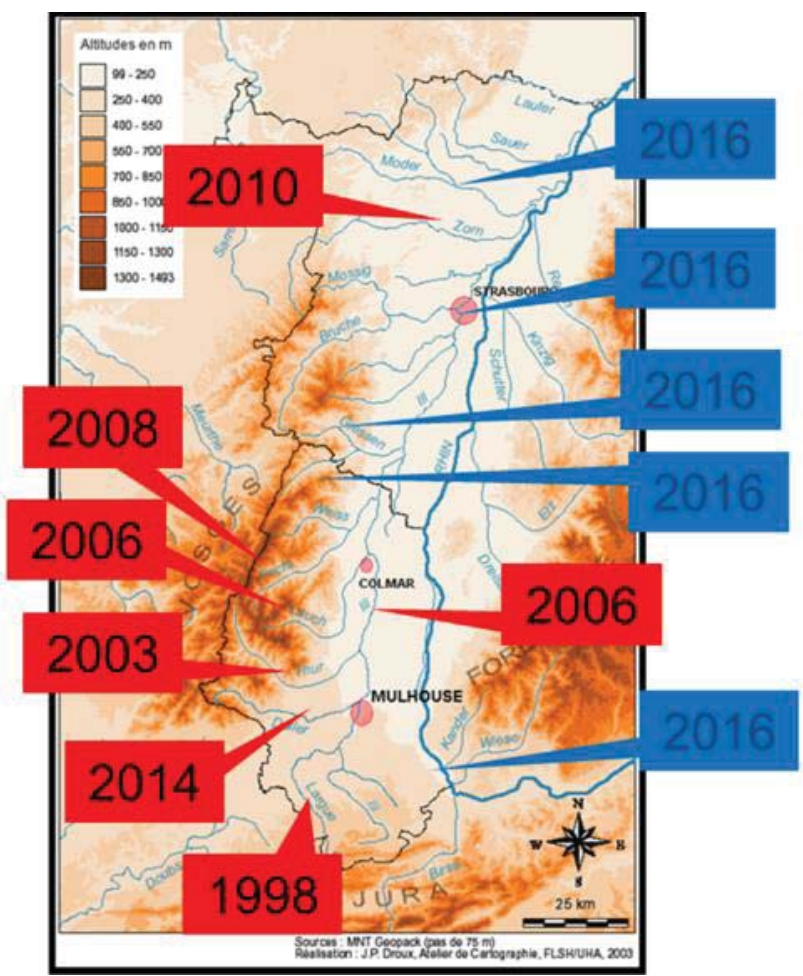

Fig.6: PPRI procedures in Alsace (in red those approved and in blue, those programed for 2016 - 2017)

Implementing risk policies or managing floods at the local scale is complex. Funding, strain between the local stakeholders, lack of citizens' interest, complexity of all the administrative procedures that can be used to prevent the risk etc., are some parameters that make it more 
complex [41]. It is also striking to see that the implementation of preventive information campaign is triggered by the necessity to obtain funding and is not seen as an essential prevention action. But, it is worth noticing that two main administrative procedures (PAPI "Programme d'Action de Prévention des Inondations") were funded because they propose concrete actions to maintain a memory of past events [42]. They both considered the implementation of flood marks as a mean to increase the "risk culture". Unfortunately their budget draft concerned only the purchase of flood marks and no other reflections had been made as the best way to reach the goal. We need then to implement a strong method to find out all the necessary information on the historical floods for laying the flood marks, by requesting both the ORRION database and the local stakeholders, these latter contributing to the enrichment of the database. All the contradiction in floods management is revealed here: some stakeholders are involved in a process of strengthening the "risk culture" but they did not really have this culture themselves. The collaboration with local stakeholders and ORRION users' feedbacks will be beneficial for ORRION's future development and use.

\section{Conclusion}

In the Rhine Graben, the (re) development of a risk culture requires to face several challenges: (1) to exceed the question of the oversight and the misunderstanding of the risks, linked to the particular geohistory of this territory, (2) to be encompassed within a cross-border and intercultural dimension, (3) to convince the actors of the interest of the approach appart from a crisis period, (4) to design tools accessible to all the actors, (5) to be part of a participative approach of a co-construction of the knowledge. In this respect, the website ORRION constitutes an interesting example, especially because it is a transposition, adapted and throughtfull, in the public domain, of a tool originally designed by and for the research. The relevance of the approach is attested by the integration of ORRION in the regulatory procedures (PPRI, PAPI, European Directive «Floods») of the Alsatian side, and moreover by an identification of the expertise by the media (print and broadcast regional media). Nevertheless, the interest and the relevance of the website ORRION will really be estimated only through its appropriation by all the actors and, particularly, the public. Yet on this point, the results remain limited. Without crisis, familiarity or risk experience, is it really possible to raise awarness of the actors concerning the high importance of the development of a risk culture ? In other words, can the prevention be efficient without « disaster culture » and disaster experience, in the French system built on an effective repair but removing responsability $^{\mathrm{k}}$ (Aviotti 2014), or in the German one

\footnotetext{
k "When floods occur an insured person carries his television down into the cellar, while a person without insurance carries it upstairs!'[12].
}

based on more individual responsability, ${ }^{1}$, but of a too high insurance-related cost to be really effective.

\section{References}

1. Martin B, Ansel R, Guerrouah O, Vitoux M-C, With L, Drescher A, Glaser R, HImmelsbach I and Schönbein J. (2011a). Géohistoire critique de la crue de janvier 1910 dans le Fossé Rhénan (Alsace / Pays de Bade). La Houille Blanche, 1, 2011, 62-68.

2. Martin B, Ansel R, Drescher A, Guerrouah O, Glaser R, Riemann D, Vitoux M-C, Vogt S and With L. (2010a). Threatening disaster or mastered risk? A geo-historical approach of flood risk in urban area. Example of Mulhouse (France), Territorium , 17, 201-209

3. Martin and al. (2010a). Ibid.

4. Slovic P. (1987). Perception of Risk, Science, 236, 280-285

5. Blesius J-C. (2013). Discours sur la culture du risque, entre approches négative et positive. Vers une éducation aux risques ?, Géographie et cultures, $\mathbf{8 8}$, 249-265

6. Beck E. (2006). Approche multirisques en milieu urbain. Le cas des risques sismiques et technologiques dans l'agglomération de Mulhouse (Haut-Rhin), thèse de doctorat, sous la direction de C. Weber et de M. Granet, Université Louis Pasteur - Strasbourg I, 282 p.

7. Gaillard J-C. (2006). La culture comme enjeu majeur de la gestion des catastrophes liées à des phénomènes naturels au sein des sociétés traditionnelles », in F. Leone et F. Vinet (dir.), La vulnérabilité des sociétés et des territoires face aux menaces naturelles: analyses géographiques, coll. Géorisques (1), Ed. Publications de 1'Université Paul Valéry-Montpellier 3, p. 43-53.

8. Langumier J. (2011), Mémoire et oubli, peur et déni : dynamiques du risque sur un territoire sinistré, November V. Pénélas M., Viot P. (dir.), Habiter les territoires à risques, Presses Polytechniques Universitaires Romandes, Lausanne, 165-184

9. Labeur C. (2013). Raconter l'inondation : quand les récits de catastrophes se font mémoire du risque, Géocarrefour, vol. 88, p. 45-54

10. Peretti-Watel P. (2010). La société du risque, Paris, la Découverte, $126 \mathrm{p}$

11. (Girard, 2004)

12. DKKV (2004). Flood Risk Reduction in Germany: Lessons Learned from the 2002 Disaster in the Elbe Region. DKKV Publication 29 ${ }^{\mathrm{e}}$, 40p.

13. Vojinovic Z. (2015), Flood Risk: The Holistic Perspective: From Integrated to Interactive Planning for Flood Resilience, IWA Publishing - Science $296 \mathrm{p}$.

14. IFEN (2005) La perception sociale des risques naturels, Les données de l'environnement, 99, 4p. http://www.statistiques.developpement-

\footnotetext{
1 La Tribune, 28/06/2013, "Pourquoi les inondations en Allemagne n'inquiètent pas les assureurs ».
} 
durable.gouv.fr/fileadmin/documents/Produits_editor iaux/Publications/Le Point Sur/2005/de99.pdf

15. Himmelsbach I. (2012). Erfahrung - Mentalität Management Hochwasser und Hochwasseschutz an den Nicht schiffbaren Flüssen im Ober - Elsass und am Oberrhein (1480 - 2007). Thèse de doctorat de l'Université de Freiburg. http://www.freidok.unifreiburg.de/volltexte/8969/

16. Glaser R, Drescher A, Riemann D, Martin B, Himmelsbach I, Murayama S. (2012). Transnationale Hochwasserrisikogeschichte am Oberrhein. In: Gebhardt H, Glaser R, Lentz S (Hrsg.): Europa - eine Geographie, Berlin, 82-88

17. Heitz C. (2005). Etude de la perception du risque de catastrophes naturelles relatif aux coulées de boue par les acteurs des communes périurbaines (Sundgau, Alsace). Mémoire de DEA, Univ. de Strasbourg

18. Ehret C. (2011). Les caractéristiques et la gestion des inondations dans la vallée de la Thur, aux XIXème et XX siècle, Mémoire de master d'histoire, Univ. Mulhouse, $148 \mathrm{p}$

19. With L. (2014). La prise en compte des évènements historiques en matière de gestion des risques d'inondation: le cas de la vallée de la Lauch (HautRhin), Thèse de doctorat d'histoire contemporaine, Univ. Mulhouse, $542 \mathrm{p}$

20. Brahim W. (2010). Mémoires, perceptions, représentations de la crue de février 1990 dans la vallée de la Lauch. Mémoire de master, Univ.de Haute - Alsace, 76p.

21. Martin and al. (2011a). Ibid.

22. Himmelsbach I. (2012). Ibid.

23. Martin and al. (2011a). Ibid.

24. Martin and al. (2011a). Ibid.

25. Martin B, Holleville N, Fournier M., Furst B, Giacona F, Glaser R, Himmelsbach I, Schönbein J, Vitoux MC, With L, (2015a). Les évènements extrêmes dans le fossé rhénan entre 1480 et 2012. Quels apports pour la prévention des inondations?, La Houille Blanche, 2, 2015, p.82-93

26. Martin and al. (2015a). Ibid.

27. Martin and al. (2011a). Ibid.

28. Martin and al. (2015a). Ibid.

29. Himmelsbach I. (2012). Ibid.

30. Martin B, Guerrouah O, Himmelsbach I, With L. (2011b). La périurbanisation et la construction des territoires du risque d'inondation en Alsace. Actes $\mathrm{du}$ colloque Association de Prospective Rhénane, Périurbanisation, créativité \& durabilité, Strasbourg, 22 novembre 2010, 119-13

31. Martin and al. (2010b). Ibid.

32. Guerrouah O. (2010). Situation de blocage d'une procédure de PPRI : la clef de l'histoire? Cas du Bassin de I'Ill (Alsace, France), Quelles archives aujourd'hui pour mieux gérer les risques demain? Approches géographiques et historiques, Nancy Meschinet de Richemond (dir), Collection Géorisques PULM Montpellier, 3, 56-61

33. With L. (2014). Ibid.

34. Martin and al. (2015a). Ibid.

35. Himmelsbach I. (2012). Ibid.
36. Himmelsbach I, Glaser R, Schoenbein J, Riemann D, Martin B. (2015). Reconstruction of flood events based on documentary data and transnational flood risk analysis of the Upper Rhine and its French and German tributaries since AD 1480, Hydrol. Earth Syst. Sci., 19, 1-16, 2015

37. Lang M, Coeur C, Bard A, Bacq B, Becker T, Bignon E, Blanchard R, Bruckmann L, Delserieys M, Edelblutte C, Merle C. (2013), Les inondations remarquables en France: premiers éléments issus de l'enquête EPRI 2011. La Houille Blanche, 5, 37-47

38. DREAL Lorraine (2013), Identification des TRI sur le bassin Rhin-Meuse. Rapport de présentation

39. Martin and al. (2015a). Ibid.

40. Hubert G, De Vansay B. (2005). Le risque d'inondation et la cartographie réglementaire. Analyse de l'efficacité, des impacts et de l'appropriation locale de la politique de prévention. Programme "Evaluation et Prise en compte des Risques naturels et technologiques", Ministère de l'Ecologie et du Développement Durable, 188 p.

41. Martin B, Guerrouah O, Ansel R, With L. (2010b). Territorialisation ou déterritorialisation du risque ? Analyse comparative et critique de la procédure de réalisation des PPRNP, RISEO, 1, www.riseo.fr

42. Martin B, Holleville N, Furst B, Giacona F, Glaser R, Heitz C, Himmelsbach I, Schönbein J, Vitoux MC, With L. (2015b). Les curiosités des procédures de gestion des risques d'inondation (PPRI, PAPI) dans le bassin du Giessen en Alsace, Actes $d u$ colloque "11 ème Rencontre Géorisque " Les Programmes d'Actions et de Prévention des Inondations (PAPI) : Expériences, bilans et perspectives ", 27-28 janvier 2015, Montpellier, France, 203-214 